\title{
The Crisis-Ridden Capitalist Mode of Production as Driving Force for Restructurations and Transformations in and of the Media Industry. Explanatory Theoretical Elements of a Cri- tique of the Political Economy of the Media
}

\author{
Manfred Knoche \\ University of Salzburg, Salzburg, Austria, manfred.knoche@sbg.ac.at, \\ http://www.medienoekonomie.at, https://kowi.uni-salzburg.at/ma/knoche- \\ manfred/, @Medoek
}

\section{Translation from German to English: Mareile Pfannebecker and Christian Fuchs}

\begin{abstract}
The goal of this article is to explain long term restructurations and transformations of the media industry. In order to do so, the article uses theory elements of a critique of the political economy of the media. The paper is a contribution to the development of theoretical approaches that provide a theoretical analysis of the media in capitalism based on Karl Marx's concepts. The capitalist mode of production is the primary driving force of media corporations strategic action and of the media economy's structural transformations. Factors that are of particular relevance in such structural transformations include profit orientation, capital accumulation, capitalist crises, state policies, behaviour of producers and consumers, private property, class relations, the antagonism between productive forces and relations of production, the antagonism of variable and constant capitalism, the antagonism of use-value and exchange-value, and competition. Competition, capital's need to survive, and capitalism's immanent crisis potentials force corporations try to create innovations such as new digital technologies. Informatisation, which includes the use of the computer as universal machine and the Internet, is the provisionally latest stage in the development of the productive forces that has affected media technologies and the media industry. The capital-driven structural digital transformation of the media industry has resulted in the convergence of production, distribution and consumption, the creation of a variety of non-tangible digital products, digital rationalisation and automation, and the universal real subsumption of labour under capital. These developments have also created the potential potentials for overcoming the capitalist character of the media economy and advancing decommodification based on the emergence of a universal digital media system.
\end{abstract}

Keywords: critique of the political economy of the media, structural transformation of the media industry, capitalist mode of production, capitalist crisis, real subsumption of labour under capital, formal subsumption, digital media, digitisation, informatisation, universal medium, universalisation, productive forces, computer, computing

Acknowledgement: This article was first published in German: Manfred Knoche. 2013. Krisenhafte kapitalistische Produktionsweise als Triebkraft für Restrukturierungen und Transformationen (in) der Medienindustrie. Erklärende Theorieelemente einer Kritik der politischen Ökonomie der Medien. In Langfristiger Wandel von Medienstrukturen: Theorie, Methoden, Befunde, ed. Wolfgang Seufert and Felix Sattelberger, 87-111. Baden-Baden: Nomos. Translated into English and publication of the translation with permission. 


\section{Communication Studies' Views of the "Structural Change" of the Media}

The goal of this article is to explain long-time restructuration and transformation of the media industry. In order to do so, the article takes a theoretical approach to the critique of the political economy of the media. Object of the analysis are not only traditional mass media, but also processes of change in an extended media and communications industry (see Knoche 2016).

The article proceeds from the central notion that the capitalist mode of production is the primary driving force of media corporations' strategic action as main "actors of structural transformations" 1 . Capitalist production, since it is the dominant mode of production, includes the social formation that bears its stamp, including the hegemonic forms of distribution and consumption and the manner of life pursued by members of a given society. It is in this sense that the capitalist mode of production is a 'driving force' that also offers explanations for the behaviour of advertisers, politicians and states, banks and sellers of information, in many ways, for the behaviour of the entire population. It is for these reasons that this piece attributes general theoretical 'explanatory power' to the capitalist mode of production.

According to the dialectical mode of thought and analysis developed within the Marxian critique of political economy (cf. Marx 1863-1865, 1867, 1885, 1894) and their recent further development by the approach of the New Reading of Marx (in particular, see Haug 2013, Bonefeld and Heinrich 2011, Harvey 2018, Heinrich 2011a, Hoff 2009, Elbe 2008), the capitalist mode of production is regarded as contradictory in principle and as essentially in crisis ${ }^{2}$. Therefore, no single linear, monocausal-determinist explanation is applied here. Instead, contradictory elements of the crisis-based capitalist mode of production will be viewed as fundamental determining factors for actions and behaviour of actors.

\subsection{Critique of Traditional Ways of Thinking}

The dominant use of the term "structural change of the media" signals a specific way of thinking, revealed in typical phrases like "a world of media that is changing itself", "a media system that is differentiating itself". In this manner, change is consecrated as "natural-supernatural", as deus ex machina, even reified as a barely explicable natural event, which comes about or takes place as a matter of fate. Accordingly, the erroneous idea is spread that companies are "affected" by change, that they have to "adjust". Continual measures of restructuration can thus appear as reaction to pre-existing change. This reversal covers up the fact that the media's structural transformation is in reality the result of companies' purposeful and strategic restructuring activity.

1 The metaphor 'driving force' is used here to imply "impulse, movens, motor, motivation", in the sense of compulsion towards actions for companies and individuals. Capitalist media companies are driven drivers that drive dependant workers in order to effect "media change" in the interest of capitalist owners.

2 The following reflections are, within the framework outlined above, only intended as a starting point for what I regard a useful application of work critical of capitalism from neighbouring disciplines to the discussion around the "structural change" of the media; work which, so far, has not been acknowledged within Communication Studies. 
Much of what, within media studies, has been rashly labelled "structural transformation" - usually with reference to technological change alone - is in fact only evidence of cyclical modification of superficial phenomena ${ }^{3}$.

\subsection{The Critique of the Political Economy of the Media's Way of Thinking}

In order to answer the fundamental question which modifications may be justly called "structural transformation of the media", it is necessary to take scientific analysis to a higher level of abstraction. In this way, modifications can be appreciated in their different qualities as more or less substantial, as fundamental phases of development, upheavals, transitions, substitutions or long-term tendencies. The author of this article will mostly consider empirically identifiable restructurations in the media industry on the level of abstraction of Marx's categories of the capitalist mode of production. With this perspective, fundamental restructurations regarding changing power relations can also be described as transformations of and in the media industry.

The possibility, in principle, of a (partial) transformation of the private sector, profitoriented media industry's mode of production into a non-capitalist media production and distribution belongs to this higher level of abstraction. It includes socially relevant transformations regarding the dominant relations of production today, alongside the antagonism between the owners of the means of production and waged or "free" workers.

Finally, it is the object of a critical analysis to ask in which areas there are no or only small modifications, for example regarding relations of production that come with specific forms of property, appropriation and legal arrangements. In my view, the identification and explanation of relevant non-modifiations is more significant for analysis as well as for practical purposes than the usual documentation of a confusing number of less relevant phenomena of "change". Such an academic interest in knowledge could stimulate research that has the aim of recognising the ideological content of various "structural change"-narratives in terms of interest-oriented legitimacy, distraction, or attempts to mislead.

While Marx has not produced a critique of the political economy of the media, there are still, in Marx and Engels' work, there are plenty of academic foundations fitted to the task (cf. Fuchs 2011; 135ff; Fuchs 2009a, b). Yet the specificity of media production as both physical and intangible, as well as the great number of different sources of revenue within it justify, or rather, demand, the development of a distinct critique of the media's political economy. Furthermore, this particular approach to the media is required because media economy fulfils a fundamental role both in the economy overall and in political ideology (cf. Knoche 2002; 2001).

The academic mode of thought that underpins the theoretical approach taken by the author of this paper can in its most general form be characterised in the following form: "all science would be superfluous if the form of appearance of things directly coincided with their essence" (Marx 1894, 956). Accordingly, the general goal is to analyse and explain multiple and various forms of appearance, on a higher level of abstraction and in a systematic-theoretical context, as essential. Marx's works are not used here as a source of incontrovertible, eternal truths, but as a valuable stimulus for the continuation of critical thinking - in the knowledge that Marx's theory, in its specific

3 Technological "change" is even often erroneously presented as causative actor, as is apparent in common expressions such as 'the Internet has effects/ requires' or 'publishers have to respond to/ become fit for the internet'. 
elaborations, includes some inconsistencies as a sign of its unfinished nature (cf. Heinrich 2011b).

A critical application of Marx's analytical method serves the theoretically led, empirical analysis and explanation of media production, distribution and consumption. A critique of the political economy of the media, under application of Marx's method as a unit and application of a historically focused analysis of form, structure, action, actor, process and function, can meet the requirements of a basic theory in Communication Studies. To meet the demands of a conventional empirical assessment in its strictest form is, however - as generally in capitalism - near-impossible, especially given that capitalist enterprises, protected by law as private entities, make excessive use of trade secrets. Instead, this attempt at theoretical explanation will build on the structural empirical method of identifying how the logic of capital links empirically identifiable structural phenomena and processes of differentiation. ${ }^{4}$

\section{Explanatory Models}

\subsection{The Capitalist Mode of Production's Tendency Towards Crisis}

In principle, the individual strategic behaviour of a given enterprise - in the interest of the owners of capital and in cooperation with government actors - is the main active cause, the "trigger" of processes of restructuration and transformation. Accordingly, they can explain structural transformation in an immediate fashion. Yet, at the same time, these patterns of behaviour and of action are mediated and prepared, generally conditioned and prearranged, if not predetermined in the individual case, by the structural, social and societal conditions and initial constellations of the crisis-ridden capitalist mode of production ${ }^{5}$. Given that capitalist media enterprises strive permanently to maximise profits (by the valorisation of capital via value-added production on the basis of private ownership of the means of production), they certainly remain under the structural pressure of contradictory laws of movement of capital, and most of all, under the pressure of competition (as essential to the driving force of the capitalist mode of production) to an extent that generally leaves little room for manoeuvre. "Marx shows how the processes of production are, in capitalist society, incessantly transformed under the impetus of the principal driving force of that society, the accumulation of capital" (Braverman 1974/1998, 6).

The following principal driving forces (and therefore scientific components of explanation) can be distinguished in general terms:

- the basic requirements of the capitalist mode of production to which the media industry is subject to the same extent as other industries;

- specific factors emerging from the crises of the capitalist mode of production that, modified by the initial historical situation of individual media enterprises, effect problems with the valorisation of media capital and are interlinked with enduring processes of capitalist restructuration;

4 Adherents of Popper's principle of falsification may therefore choose to consider my theoretical attempts at explanation as hypotheses that can claim validity until the point were they will be empirically falsified.

5 Crisis is an enduring and essential element of capitalist production. Crisis and change condition each other in a permanent process. It is therefore academically quite shortsighted when a book title asks "media change or media crisis?" (Medienwandel oder Medienkrise?) and thereby opposes change and crisis and reducs the media crisis to a funding crisis or even to a funding crisis of newspapers (cf. Jarren et al. 2012, 11ff., 165ff.). 
- strategies of companies that have to date acted outside the media industry, which are now built up as new media enterprises in order to exploit favourable opportunities for profit maximisation;

- strategies of the advertising sector;

- interaction with the "unleashing tendencies" of the state's economic (media) policy (privatisation, deregulation, the promotion of concentration, judicial policy etc.);

- patterns of behaviour by members of society as consumers or producers with different agendas: a thus far dominant majority that does or would like to participate in the "structural change" afforded by the capitalist mode of production ("sharing", "prosumers"), or a minority that adds non-capitalist elements (non-commercial production and distribution, e.g. as public goods or creative commons).

As a general rule, the specifics of elements in a given mode of production characterise the social formation attached to it (cf. Resch/Steinert 2011, 41ff). Marx articulated the characteristics of the capitalist mode of production, in the first instance, in order to distinguish epochs of different dominant social formations alongside different historical modes of production (of antiquity, Asia, feudalism). From this perspective, the capitalist mode of production appears broadly constant/ unvarying. That said, Marx also pointed to a periodisation within capitalism on the basis of significant transformations of the capitalist mode of production. These ideas are taken up now, within the critique of capitalism in the contemporary discussion, even with a view to the possibility of a transition to a non-capitalist mode of production via transformation (transcendence) or revolution (cf. Haug 2008).

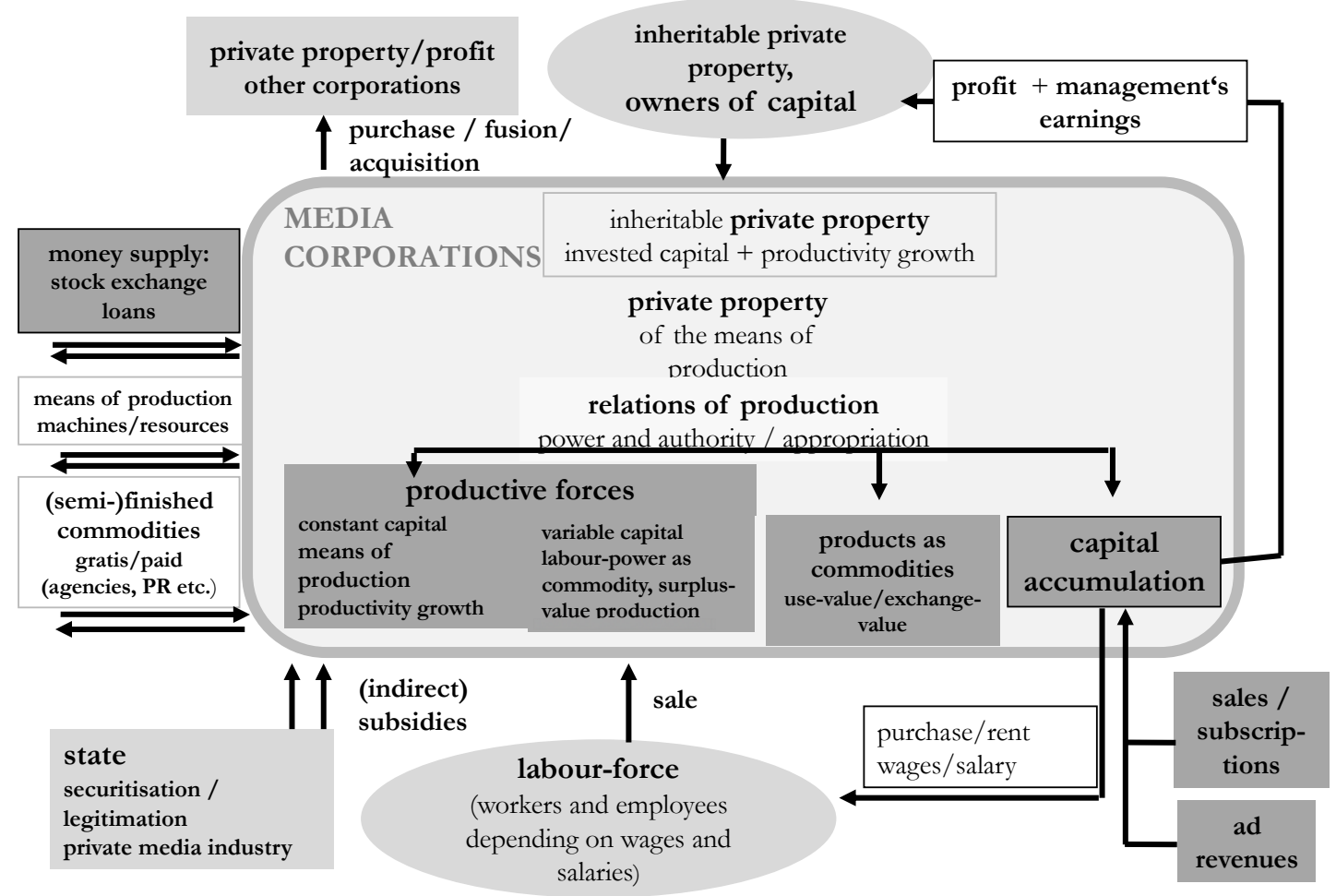

Figure 1: The capitalist mode of production in the media industry

For the owners of capital, what is at stake is thus also to effect suitable modifications 
of the capitalist mode of production to prevent transformations directed against their interests. In their stead, and as a matter of principle, they only initiate restructurations and transformations that optimise the valorisation of capital and secure the relations of capital as well as the capitalist social formation. In this way, the process of formal and real subsumption of society under capital is expedited (cf. Brandt 1990, 181-, 254ff; Schmiede 1989; 2006; Mendner 1975; Marx 1863-1865, 1019-1038; Marx 1867, 645). The main determining factors (driving forces) for long-term restructuration- and transformation activity are the following, broadly constant elements (see Figure 1) of the necessarily crisis-driven capitalist mode of production:

- the protection by law of (inheritable) private ownership of the means of production and its goal, the accumulation of capital for the sake of profit maximisation;

- the relations of production as the rule of owners of capital over workers (power of disposal over labour-power as commodity and appropriation of the surplus value generated);

- the exclusive right to determine the goals of production and the accordant use of capital;

- the appropriation of products by the owners of property.

We find the following principal, variable, crisis-ridden elements of the capitalist mode of production:

- the antagonistic interdependency of the productive forces and the relations of production;

- within productive forces, a contradictory relation of constant (means of productions) and variable capital (workers);

- the contradiction between the use values and exchange values of commodities;

- the realisation of surplus value and exchange value (rate/sum of accumulation and profit)

- the stabilisation of the mode of production via the cooperation of owners of capital and state.

The driving force of competition is the essential component of the capitalist mode of production. Competition forces all enterprises to engage in fundamental and wideranging restructuration and transformation as key method to get ahead in the permanent battle for hegemony, especially via the restructuration of productive forces.

\subsection{The Dialectic of Productive Forces and Relations of Production}

The capitalist mode of production is marked by a dynamic interrelationship between historically specific productive forces and relations of production. Due to unclear and ambiguous statements by Marx on the topic (e.g. Marx 1847, 165-166) it remains a matter of dispute which of the two elements is dominant in their relation to each other, and beyond, which is decisive in the development of the capitalist mode of production and capitalism as a social formation. Marx's emphasis on the primacy of material productive forces has, for some, evoked the controversial idea of automatic revolution once productive forces reach a particular level of development:

At a certain stage of development, the material productive forces of society come into conflict with the existing relations of production or - this merely expresses the same thing in legal terms - with the property relations within the 
framework of which they have operated hitherto. From forms of development of the productive forces these relations turn into their fetters. Then begins an era of social revolution (Marx 1859, 263).

In contrast, this article considers relations of production as relations of rule, and the actions by owners of capital that are based on it as the decisive driving force for the development of productive forces (means of production and labour). Productive forces under capitalism are often developed in such a way that the technological development of means of production becomes an essential means for the increase of labour productivity. The restructuration of the production process, which takes the form of reorganisation and control of the labour process, becomes possible on the basis of the means of production, and with it, an increase in labour intensity. In principle, this also effects a modification of the relations of production, in that they effect modifications in the power relations between owners of capital and the workforce. Such modifications can, depending on the kind and significance of the increase or loss of power ${ }^{6}$, be finally considered as relevant modifications of the capitalist mode of production and the capitalist social formation (the transformation of capitalism).

\subsection{The Compulsion to Innovate and Produce: Structural Overaccumulation, Overca- pacities and Overproduction}

Capital, usually copiously accumulated ("overaccumulation"), forces competing enterprises to innovate and to produce, with the aim to avoid the (usually latent) threat of a crisis that might lead to the reduction of surplus value and rates of profit and so the devaluation or destruction of capital. Independently from this pressure, strategies of innovation are implemented in order to further the concentration of capital and markets ${ }^{7}$.

Problems of structural overaccumulation generally consist of the amassing of too much capital, in the sense that surplus capital cannot be exploited with an appropriate rate of profit. It is a fact that, in the decades after 1989, media enterprises were able to temper their problems of overaccumulation by expanding to the formerly socialist countries. But, at the same time, the attendant accelerated increase of capital still exacerbated those problems. Structural overaccumulation, and the overcapacity and overproduction that come with it, are expressions of the contradictory nature of the capitalist mode of production (cf. Kisker 1997).

6 We might place the discussion regarding the autonomy or dependency of journalists in this context.

7 The usual means to solve overaccumulation problems, or to prevent them in the first place, are the buying and selling of companies and shares in companies, concentration activities, as well as the opening up of new lines of business. 


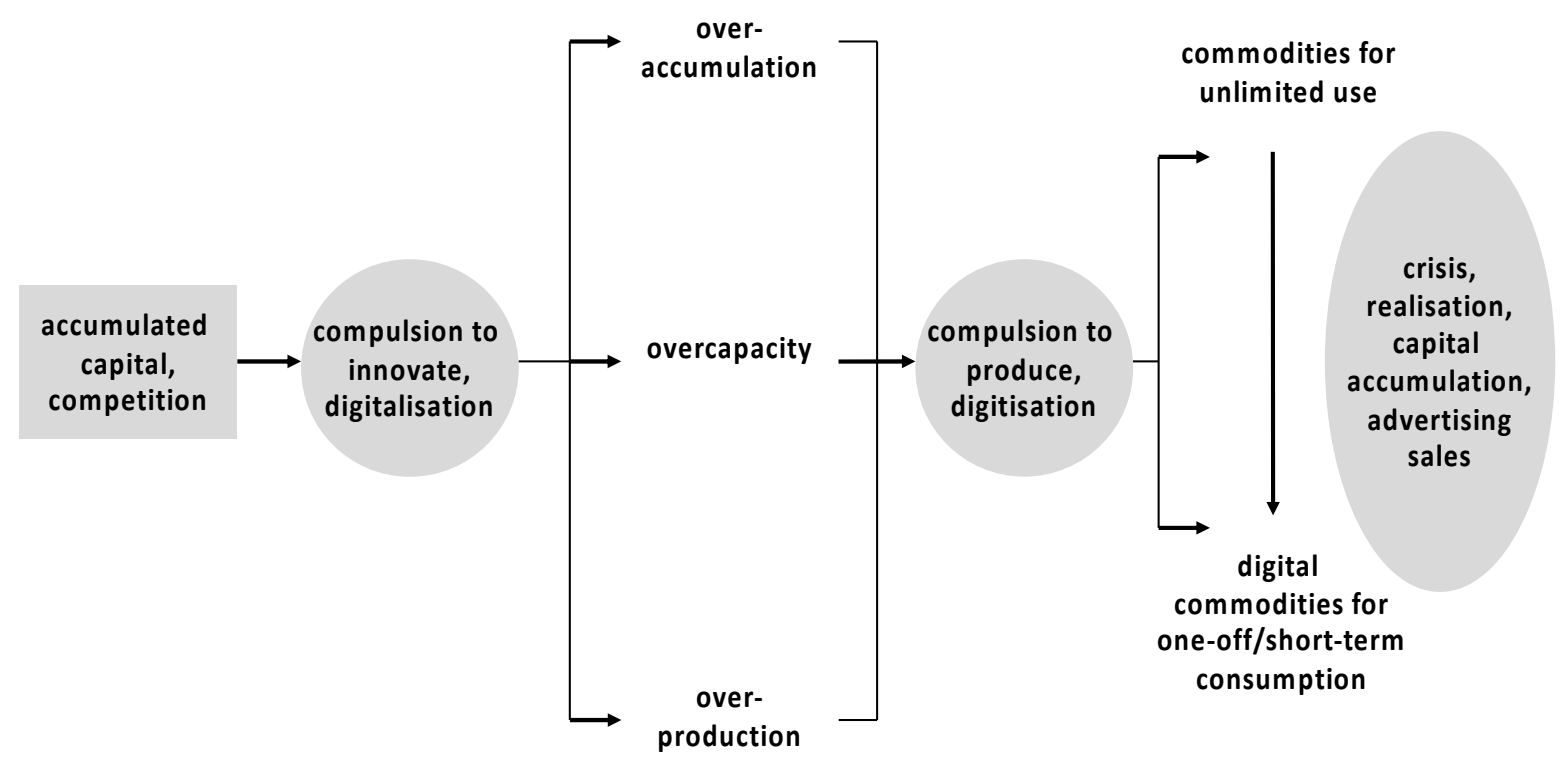

Figure 2: Capitalism's immanent, permanent crisis-ridden structural overaccumulation: the compulsion to innovate and produce in the example of digitisation

Accordingly compelled to increase innovation and production (see Figure 2), the entire media industry produces as many digital commodities for one-off or short-term consumption as possible, so that individual media enterprises will inevitably, if to a variable extent, suffer crises in the realisation of accumulated capital via insufficient proceeds from sales and/or advertising.

\section{The Media Industry's Restructurations}

Within the framework of a critique of the political economy of the media, the author in this article seeks theoretical explanations on the basis of elements of the capitalist mode of production; these explanations are focused, under application of Marx's terms and categories, on the fundamental processes of long term "structural change" in and of the media industry that take the shape of restructurations and transformations ${ }^{8}$. In what follows, these will, by systematic abstraction, be categorised as substantial modifications in form and formation, driven principally by the strategies of media enterprises "as a gradual and diversified process of restructuration" (Dolata and Schrape 2013, 8). Current modifications in the media industry are centred on processes that can be understood as "catch-up industrialisation and tendencies towards the Taylorisation of intellectual labour" (Teschner and Hermann 1981, 129). ${ }^{9}$

In the first instance, I focus my analysis of such long-term transitional processes on three essential and interrelated entrepreneurial areas of restructuration (all conditioned by the capitalist mode of production): a continual, principally technologically mediated

8 Economically, restructuration is understood as "a non-crisis causing, planned and focused modification of organisational structures, processes and systems to the end of increasing effectiveness and efficiency" (http://www.daswirtschaftslexikon.com/d/restrukturierung/restrukturierung.htm (16.4.13)). Restructuration is more comprehensive than the equally common term reorganisation.

9 Accordingly, there is also a required catch-up in industrialisation in scholarly reflections within Communication Studies as well as in the consciousness of media workers. 
restructuration of productive forces, connected to modified restructurations of the relations of production and the capitalist mode of production in the interest of the valorisation of capital. Media owners drive these transitional processes in individual competition with each other, as they pursue the same interests that all owners of capital in all industries and branches of industry, but also in partial cooperation in the common interest of all owners of capital (for example regarding waged workers, consumers and the state).

\subsection{The Productive Forces: Universal Informatisation and Universal Automation}

The driving force of the capitalist mode of production becomes especially apparent in the continual restructuration of productive forces (means of production and the labour force's manner of working) that is an existential requirement for the owners of capital. These restructurations are a basic method to increase, in the interest of capital, productivity, distribution and consumption. It is for this reason that the development of productive forces is often regarded as the main indicator for the distinction of historical levels of development in the capitalist mode of production. This approach is also expressed in terms like "highly technological mode of production" or "high-tech-capitalism" (cf. Haug 2005; Ohm and Haug 2004; Haug 2012; 2008; 2003).

Likewise, the "outline for a theory of the productive force of the media" divides the development of communication technologies as productive forces of communication (art, culture, media) into consecutive phases of transformation and formal modification as graphic, electronic and digital "media metamorphoses" (cf. Smudits 2002, 73ff.). A process seen as related is the continuing industrialisation of cultural activity, which comes with a transition from a purely formal subsumption under the capitalist mode of production to a real one (cf. Smudits 2002, 146ff.).

Over the last few decades, one can observe in the media industry, just as in the rest of society, a discernible development of "informatisation as productive force" (Boes and Kämpf 2012); that is, the restructurations of processes of production and labour are based on the integral use of microelectronics and the internet (cf. Sauer 2006, 89). This process is even considered by some German sociologists of labour and industry as "a structural transformation of the mode of production" (Schmiede 1996, 15). The term "informatisation" denotes a social development of the productive forces within which intellectual activities (intellectual labour) are subjugated, via computerisation with client-server-conceptions and the Internet as a worldwide "space of information", to the capitalist industrial process of production and exploitation in the form of "real wage labour" to denote a "new phase of capitalism" (Boes and Kämpf 2012, 317, 326).

In comparison to the previous period of mechanisation, the separation of manual and intellectual work tends to be reversed. Intellectual work is no longer organised according to individual capacity vouched for by qualifications, but is instead integrated into processes supported by computer software (computerisation of intellectual labour). This also facilitates new possibilities for the control of labour and the production process, but most of all the direction of production towards the market, which comes to pass as the valorisation-oriented, flexible standardisation of production by automation (cf. Benz-Overhage et al. 1982). In this way, "services by individual subjects that, until this point, had escaped capitalist control, are by virtue of the productive forces' new structure, newly integrated into capitalist valorisation processes" (Boes and Kämpf 2012, 330).

Finally, the restructuration of technological productive forces also serves as a means to stabilise or modify the relations of production as relations of domination or 
dependency. As a consequence of the de-individualisation as well as the de-qualification of workers, effected by the use of computers as universal machines for the farreaching automatisation of production, in the context of the situation on the labour market where we find the tendency of journalists becoming "superfluous and a substantial "industrial reserve army" (unemployment, precariat), power relations are altered significantly in favour of capital at the negative expense of waged and freelance journalists (cf. Schmiede 1996, 44-45).

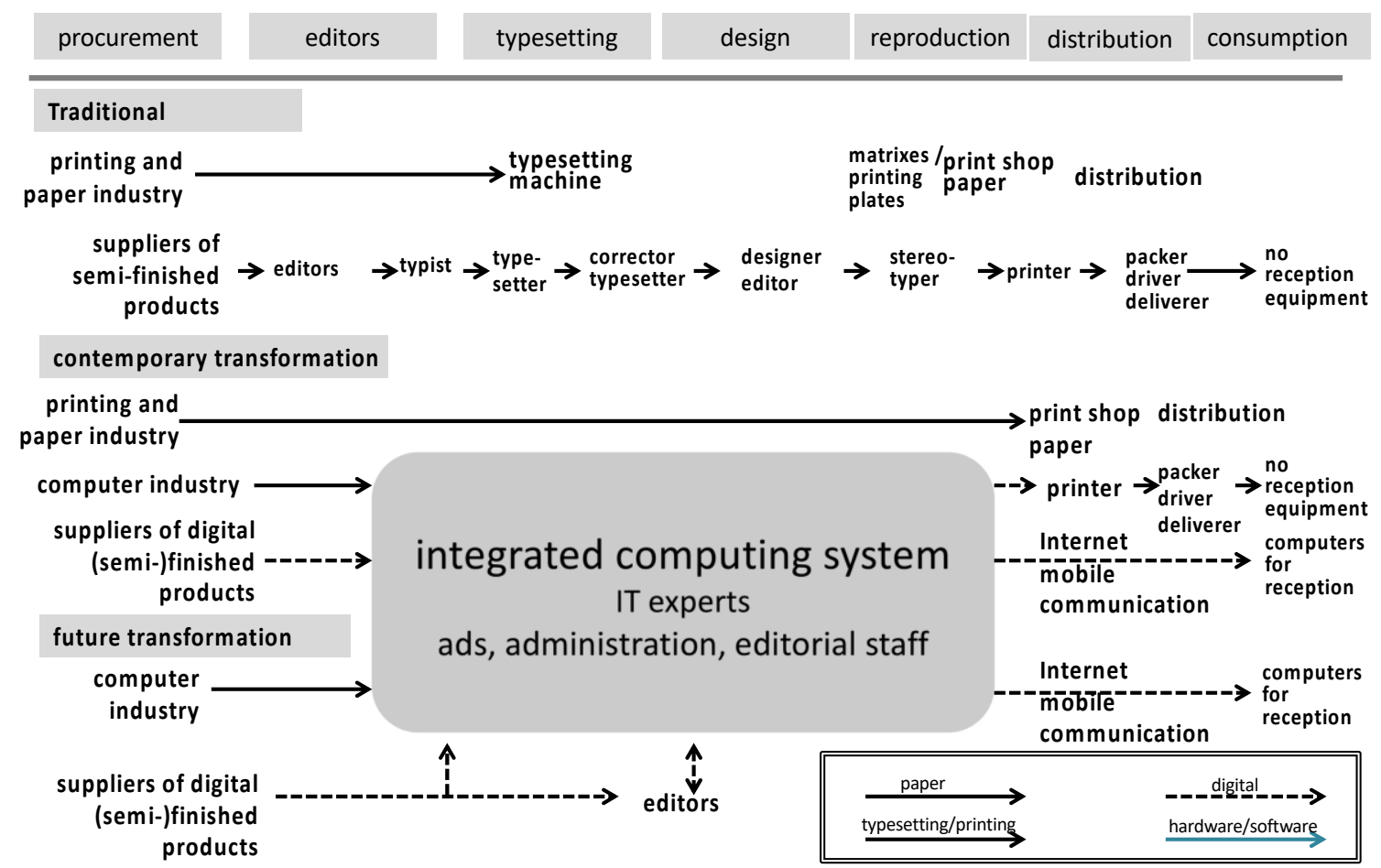

Figure 3: The restructuration of the productive forces in respect to media production, media distribution, and media consumption

This is why, since the 1970s, the restructuration of productive forces (see Figure 3) has been driven by publishing houses in a continual process initially only inside companies. Weischenberg (1982) already described this process in its early phase as "technological change of the media", characterised by mechanisation, automation, informatisation, rationalisation and Taylorisation. This restructuration took its course over several phases, initially against the futile resistance of typesetters, printers and journalists. Figure 3 sketches the three phases of restructuration:

- First, the starting point of the traditional means of production and organisation of labour: only material production with composing room, page make-up, reproduction (print and paper) and distribution. The means of production are controlled by the print- and paper-industry.

- Second, the restructuration as transitional period, during which the means of production are controlled by print- and paper industry as well as by the computer industry. Even in this early phase traditional physicall production was already gradually digitalised (only printing without plate and distribution as "remainder" of material production), but production was still confined to physical publishing products. Yet, many workers from traditional professions in physical industrial production were rendered obsolete alongside the corresponding steps in the production process. During 
the rest of this stage of restructuration, physical/tangible and intangible (digital) production were conducted on the basis of separate production processes in a complementary manner ${ }^{10}$.

- Third, the already foreseeable, future transformation of productive forces, which will be defined by the total dismantling of traditional means of production and the transition to exclusively intangible production. The computing industry alone will dictate the means of productions. Some media enterprises have already concluded this transition for some of their products, the rest are currently still working on the integration of physical/tangible and intangible production.

\subsection{The Relations of Production: The Universal Real Subsumption of Labour Under Capital}

The "driving force" of the capitalist mode of production is rendered visible in the continual attempts by owners of capital to pursue the real subsumption of labour under capital via the restructuration of productive forces. This means that production- and labour processes are increasingly fine-tuned to the valorisation interests of capital. Within the context of this continual expansive capitalisation of the media industry, the formal and real subsumption under capital also presses ahead in areas of art and culture (painting, sculpture, photography, theatre, opera, concerts, dance, museums etc.) as well as of the Internet and of individual communication (including "social media") that had so far been only marginally affected or not subsumed at all (cf. Knoche 2001; cf. Smudits 2002, 146ff.)

Marx distinguishes between formal and real subsumption, first, in order to differentiate the capitalist mode of production from the pre-capitalist (feudal) mode of production, and second, in order to show the phases of development of the former ${ }^{11}$. For Marx, the real subsumption of labour under capital results in the emergence of the "specifically capitalist form of production" (Marx 1863-1865, 1024). There are some problems with the criteria Marx uses to distinguish between formal and real subsumption, particularly regarding the differentiation between absolute (increase of work time) and relative (intensification of work) production of surplus value and the development of the productive forces of manufacturing and (big) industry. For Mendner, it is clear that "the real subsumption of labour under capital was conducted since its beginnings and did not have to wait for the technological adequacy of the means of production in the shape of machines. Real subsumption does not only take place in the phase dominated by relative production of surplus value" (Mendner 1975, 33).

It therefore makes sense that Mendner distinguishes only two phases of real subsumption according to the development of productive forces: a phase of mechanisation and a phase of automation.

By contrast, Herkommer and Bierbaum $(1979,159)$, on the one hand point out that "formal subsumption always remains the basis of capitalist production", and on the other state that "the extension of the work day as a method for the extraction of (absolute) surplus value is not limited to the so-called phase of formal subsumption".

In the 1970s and 80s, Marx's theory of formal/real subsumption was the foundation of theoretically led, extensive empirical study in industrial sociology at the Frankfurt

10 Currently many media enterprises are increasing the integration of physical and intangible production.

11 Subsumption signifies the direct subordination/submission of labour or labourers as waged workers, and more generally of the production and labour process under the conditions for the valorisation of capital (production of surplus value). 
Institute for Social Research (cf. Eichler et al. 2010; Brandt 1990; 1984; Schmiede 1989; Institut für Sozialforschung 1981) ${ }^{12}$. Most cited was the modification of the theory by Sohn-Rethel $(1972 ; 1978)$. That said, the proposal was substantially revised on the basis of empirical study, as well as on a theoretical basis by Sohn-Rethel himself, especially in terms of the original "revolutionary-theoretical" assumption of an "alternative, system-transcending formal law" (Brandt 1981, 46).

Schütt, in his application of the theory of formal/real subsumption to the early phase (1970s) of the restructuration of productive forces at press enterprises, that is, the computerised material production via computer-based word processing systems, suggests that the subsumption of journalistic labour under the capitalist press remains merely formal, since they brought "no qualitative, but merely organisational modifications of the labour process" (Schütt 1981, 99). Journalistic labour, according to Schütt, was "principally determined, due to its material characteristics, by the subjective capacities of the journalist" (Schütt 1981, 99). He assumes, in the traditional manner, that there is a distinction between mental and material production. Even though, in discussing the introduction of computer-controlled word processing, he describes many features that, according to Marx's criteria are markers of real subsumption, he does not recognise the transition to real subsumption. Schütt's conclusion is based on the neglect of various relevant features of real subsumption for the sole focus on manual labour/ manufacturing, which Marx had listed, amongst others, as a marker of formal subsumption.

In contrast, Jansen $(1983,216,236,252,256)$ at least recognises "moments of real subsumption" in the introduction of computer-controlled word processing, that is, the productivity-enhancing restructuration of journalistic work (integration of intellectual and manual work) that produces relative surplus value.

According to the most relevant criterion of immediate subsumption under the conditions of capital valorisation, real subsumption in truth begins with the wage dependency of journalists and their fitting into the division-of-labour-based, industrial capitalist production and valorisation process. Since then, three stages of the gradual intensification of real subsumption regarding the criterion of the progressive informatisation (automation, abstraction of labour) of journalistic production can be identified. In these three stages, the restructuration or transformation of technological means of production are decisive means towards the "revolution" of the productive forces (with the increase of labour productivity), and towards those of the relations of production (organisation and control of labour):

- 1970s: electronic, in-house, computer-based word processing as well as the crosscompany electronic computer-controlled news communication facility of the German Press Agency (DPA),

- 1980s: microelectronic, cross-company, integrated content management systems (workflow control for editing, adverts, technology, controlling, marketing, supply chain, sales monitoring, total quality management etc.),

12 This period at the Frankfurt Institute for Social Research, during which Gerhardt Brand was Theodor Adorno's successor as director of the institute between 1972 and 1984, and which saw scientific research led by Marx's work, is completely neglected in the available and substantial histories of the Frankfurt School (cf. Eichler et al. 2010, 164). 
- 1990s onwards: Internet-based, microelectronic, cross-company, integrated content management systems with automated cross media publishing, dynamic publishing, digital publishing, multi-format publishing etc. ${ }^{13}$

Even the apparently precapitalist mode of production by apparently "self-employed" or "freelance" workers as "owners of the means of production" and individual "free sellers of commodities" is no advantage in the case of "merely" formal subsumption, since, via the integration into the content management system, they are subsumed under capital in a "quasi-real" fashion. What becomes apparent is a double strategy of media capital: one the one hand, to exploit the advantages of real subsumption of a variable, constantly reduced "core staff", whilst on the other to avoid the aspects of real subsumption that are potentially disadvantageous for owners of capital (pay rate agreements, labour committees, potential processes of identification by workers, acts of solidarity, collective action etc.) by outsourcing and offshoring. This combination of formal and real subsumption, which, via universal computer technology, is a form of universal-real subsumption, is the basis of the optimal valorisation of capital, particularly via the minimisation of wages or payment for waged and "free" labour facilitated by it.

\subsection{The Capitalist Mode of Production's Dialectic of Universal Real Subsumption Under Capital and "Potentials of Liberation"}

In the first instance, the described processes of restructuration that result in a universal-real subsumption of labour under capital provide the foundation for the increased prosperity of established and new media enterprises and for further concentration processes of. But there also are contradictions in the development that can be regarded in terms of their "liberation potential" to partially overcome the capitalist mode of production. ${ }^{14}$ They include:

- the dismantling of structural production and distribution monopolies of capitalist media enterprises (that previously facilitated the exclusion of "non-commercial", "free", "alternative" media production) via miniaturisation, reduction in cost and standardisation of digital means of production, distribution and consumption, as well as the enormous reduction in cost (fixed and variable) for production and distribution; in relation to this, reduced dependency on investment capital (as there no longer is a dependency on capital intensive industrial machinery in traditional media sectors);

- the dismantling of structural "gatekeeper" monopolies previously held by capitalist media enterprises by direct communication with consumers that circumvents media enterprises via news, PR and advertising agencies, enterprises, political parties, state institutions, social organisations etc.

\section{The Media Industry's Transformation}

Beyond the restructurations discussed so far, substantial and fundamental restructurations can also be seen as substantial qualitative transformations. These are most apparent with a view to modifications in the form of media products, the form of capital valorisation and of media formation. This is also the area were the particularities of the

13 In the US, 'robot journalism', that is, mechanically generated production of text by programmes like 'narrative science' for sport, finances and real estate are already trialled (cf. Frankfurter Allgemeine Zeitung 4 April 2012 - http://www.faz.net/-hbj-6yw8g (accessed on 29 October 2019)

14 For more details on "iberation potentials" see Knoche 2014. 
media industry that set it apart from other industries become apparent. Regulated in the interest of the dominant owners of capital, these transformations will remain only partial transformations so long as complementary forms of capital valorisation based on complementary forms of products can bring overall higher profits than a total transformation. ${ }^{15}$

\subsection{The Media Product Form: Universal Dephysicalisation, Universal Detemporalisa- tion, Universal Despatialisation}

The technologically mediated general modifications of media products via digitalisation is of a fundamental nature, and such that the characterisation of this modification as a transformation that reaches beyond individual restructuration appears justified. That said, and against the over-the-top, often misleading ideological use of terms like "immaterial" or "dematerialisation" regarding labour, production, goods or even the entire economy, it is necessary to define what precisely is different in media products today in comparison to their traditional forms (cf. Haug 2003, 97ff.).

The content production of texts, music, etc. has as "intellectual" production always been "immaterial". What is modified is merely the form of their material reproduction/duplication as they are materialised on carriers like paper, CD, etc. A detachment from carriers has taken place since the beginning of radio and television. But the necessity of materialisation as condition for the consumption of "immaterial" products has principally remained. This materialisation has been limited to consumer devices.

In essence, the current transformation of the forms taken by media products that were traditionally books, the press, audio, video and film is only a "catch-up development" in comparison with radio and television. As a consequence, the transfer to physical (intermediate) carriers and thus the physicality of the products are eliminated and the physicalisation/objectification, novel for books and the press, is focused on devices of use.

The fundamental novelty/otherness of modified media products lies, and this also applies to the electronic media radio and television, in their universalisation via digitalisation and their consequent dephysicalisation, detemporalisation, and despatialisation. On this basis, new forms of "immaterial" labour (for example "online journalism", "prosumers") and new forms of consumption ("interactivity") are developed via their materialisation on new forms of consumer devices. What is fundamentally new also becomes apparent in the attendant transformation's modification of the conditions for the valorisation of capital that are the reason for these transformations of media products. For example, on the basis of:

- convergence of hitherto separate forms of communication text, audio, image, sound, language, audio vision into universal forms of communication with additional, more complex html-based forms of communication (blogs, postings, links, animations, interactivity etc.);

- abolition of the distinction between press products according to rhythms of publication (daily, weekly etc.) and forms of publication (newspapers, magazines etc.) and replacement of it with "24 hour real time journalism" that is equally permanent and independent of place and time for everyone (as already the case in news agencies);

15 It is in this way that the staging of a nervous search for 'new business models' as the supposed main problem of 'structural media transformation' is misleading, a manipulation by enterprises and an error committed by those who believe and reiterate it. (cf. Knoche 2014). 
- automated production for diverse universal consumer devices (PC, smartphone, tablet etc.) "without metabolism", that is, without expensive and carrier-specific physical duplication and distribution.

The fundamental significance of the transformation of the media product form for media enterprises becomes especially clear with a view to the unique possibilities for the valorisation of capital that it creates: only one original must be produced and then acts as universal, original digital copy. The sale of this original does not include a change of owner, or a time-limited change of hands as in the sale or renting out of physical (media) products; instead, the original remains, regardless of the number of reproductions (downloads) the property of the producing media enterprise. It thus is neither sold nor used up.

\subsection{The Form of the Valorisation of Capital: Systemic Rationalisation and Capital Ac- cumulation in the Context of the Modification of the Media Product Form}

Typical for capitalism's most recent development is a general move towards systemic rationalisation as a phase of continual enterprise reorganisation, including increase in flexibility, integration and networking based in a comprehensive informatisation of production and distribution processes (cf. Sauer 2006). The use of developed information and communication technologies serves the central purpose of achieving a radical reduction of production cost and a stabilisation/increase of the rate and extent of profit by systemic rationalisation. This goal is decisively met by a technology-based restructuration of the mode and organisation of labour and the resulting increase of productivity.

Integrated content management systems, used as computer-, Internet- and mobile network based universal instruments of production, direction and control, are applied more than thus far to orient the content of media products towards the demands of the market, also regarding submission to the political and cultural editorial line that takes the form of automatised factual constraints. So even journalist become, more than hitherto, a systemically integrated "driving force of the process of valorisation", even as they maintain their traditional sense of self in terms of subjective freedom, autonomy, self-directed work or even their view of themselves as able critics (Baukrowitz 2006, 112).

With the use of computer technology, capital succeeds in the realm of the media industry in substantial contrast to other industries to radically lower the costs for procurement, production and distribution by focusing on the creation of "immaterial"/intangible online products. The fixed and variable costs per single unit of an intangible commodity converge towards zero. And capital also succeeds in radically lowering fixed constant capital (the costs of the means of production) because there is no longer a need for the printing/reproduction and distribution of physical products. Furthermore, a structural modification of the organic composition of (fixed constant) capital can be realised by increasing the share of the means of production as constant capital in relation to the share of labour-power as variable capital. This change of the organic composition of capital is usually achieved by reducing the number of workers whose labourpower is replaced by production technologies. At a whole, these developments create in comparison to all industries focused on physical production (e.g. the car industry) a unique foundation for the increase of the rate and mass of profit.

In particular specialised companies in the media sector producing the "classical" carrier media of the press and books face the economic and political necessity to un- 
dertake transformations in the form of systemic rationalisation. In the realm of the carrier media of audio, video and film, there is an attenuated necessity for such rationalisation. In the realm of the already largely digitised electronic transmission media of radio and television, this necessity is further attenuated.

Because of the necessarily high importance of the role that the applied media technologies play as instruments of rationalisation, the profit-maximising industry producing means of production (that is moved by the driving force of the capitalist mode of production) exerts an elementary, strong pressure. This industry produces universal digital media technologies that are media companies' means of production as well as uniform means of production and consumption for producers and consumers. These universal digital technologies are unitedly universal for all realms of society, which constitutes one of the main tendencies of the media industry's transformation.

Accordingly, the actions of the industries that provide the means of production, distribution and consumption - also driven by the capitalist mode of production - emerge as real "driving force" behind the actions of media enterprises. Especially print media enterprises are correctly identifying their chance to solve acute or foreseeable capital valorisation problems not only through enormous reductions of costs (investment capital, fixed productions costs and especially the variable cost of reproduction and distribution). ${ }^{16}$ But also - and this has so far not been duly acknowledged - by immense increases in proceeds. ${ }^{17}$ Further means for the stabilisation or increase in profits are:

- an enormous intensification of journalists' labour in the form of increased work quotas, achieved by technologically facilitated increase in the rate of labour, modifications in the organisation of labour, but also by unpaid "over-time" (cf. Fuchs 2005);

- a radical reduction in production time as well as in the timed needed for the circulation of goods and capital;

- the integration of ecommerce, marketing, advertisement and social media (marketing and prosumers);

- a shift of distribution costs from media enterprises to consumers (costs for device technology with short innovation cycles, transmission costs for internet and mobile communication) on the basis of a universalised, digital technological infrastructure for production, distribution and consumption;

- the transformation of hitherto long-term use of goods (media technology and content) into short-term consumption via limited access rights (e.g. streaming, automatic deletion of downloads, copyright restrictions etc.), strategies for short cycles of product innovation in combination with inbuilt obsolescence (cf. Knoche 2005), and the conversion of bundle-based goods (newspaper, magazine, CD, DVD etc.) towards individual items of piece goods (texts, articles, individual tracks of music etc.) sold or rented out individually.

\subsection{Media Formation: The Universal Form of Production, Distribution and Consump- tion and the Universalisation of the Media Industry}

Media enterprises conduct the transformation of the media formation via the universalisation of the media industry (Knoche 2016). This universalisation comes alongside a

${ }^{16}$ Current complaints by publishers about reduced turnover are thus in no way and indication of reduced profit.

17 So, the technologically based modifications of the capitalist mode of production, actively pursued by enterprises of the extended media industry, also facilitates the new profitable 'business models' (cf. Knoche 2014). 
restructuration or dismantling of traditionally separate media sectors, in particular regarding carrier media. The dismantling particular affects parts of business and trade capital bound up with the traditional distribution of carrier media (wholesalers, book trade, CD trade, rentals etc.). It goes hand in hand with the subsumption of work which had hitherto been unproductive for media industry capital, and which has now been 'transformed' into productive labour (Braverman 1974/1998; Marx 1862-1865).

In the current transitional phase, there is a push for the universalisation of the media industry. It takes the form of a successive restructuration of media communication, from traditional carrier or transmission media (production, distribution, consumption) to universal online and mobile communication (see Figure 4). The distribution of uniformly universal, digitalised media products again proceeds via various universal transmission networks (digital-electronic broadband cable - and wireless networks, especially internet and mobile telephony). Consumption takes place via combined, diverse universal consumption devices (Internet TV, PC/ notebook, tablet and smartphone).

This integration of sectors in the media- and communication industry via partial universalisation on the levels of production, distribution and consumption is pursued, during the transitional phase, as complementarity (multiple valorisation) of traditional and universal media alongside each other, but leads up to the establishment of central world wide universal media in the form of media portal or platforms to the ends of the substitution of carrier media book, news press, audio, video and film. Established large enterprises, which had already been restructured as multi-media corporations for some time, are forced to push ahead with these universalisation processes in intensified competition with each other, as well as with the new, highly capitalised large enterprises that are already fully universalised.

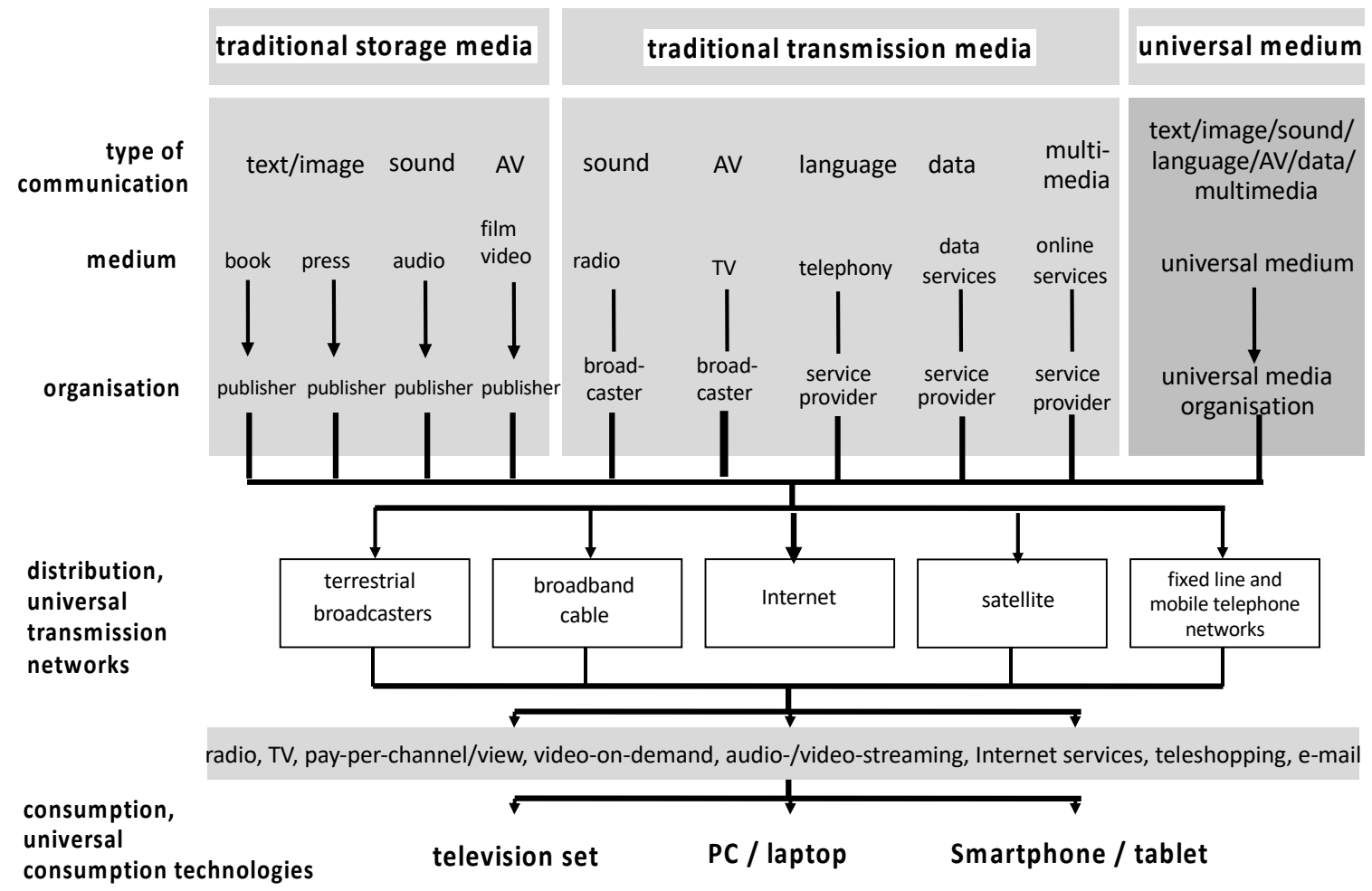

Figure 4: The transformation of the media formation: the media industry's partial universalisation 


\section{References}

Baukrowitz, Andrea. 2006. Informatisierung und Reorganisation. Zur Rolle der IT jenseits der Automatisierung. In Informatisierung der Arbeit - Gesellschaft im Umbruch, ed. Andrea Baukrowitz, Thomas Berker, Andreas Boes, Sabine Pfeiffer, Rudi Schmiede and Mascha Will, 98-115. Berlin: Sigma.

Benz-Overhage, Karin, Gerhard Brandt and Zissis Papadimitriou. 1982. Computertechnologien im industriellen Arbeitsprozess. In Materialien zur Industriesoziologie, ed. Gert Schmidt, Hans-Joachim Braczyk and Jost von dem Knesebeck, 84-104. Opladen: Westdeutscher Verlag.

Boes, Andreas and Tobias Kämpf. 2012. Informatisierung als Produktivkraft: Der informatisierte Produktionsmodus als Basis einer neuen Phase des Kapitalismus. In Kapitalismustheorie und Arbeit. Neue Ansätze soziologischer Kritik, eds. Klaus Dörre, Dieter Sauer and Volker Wittke, 316-335. Frankfurt am Main/New York: Campus.

Bonefeld, Werner and Michael Heinrich, eds. 2011. Kapital \& Kritik. Nach der „neuen“ MarxLektüre. Hamburg: VSA.

Brandt, Gerhard. 1990. Arbeit, Technik und gesellschaftliche Entwicklung. Transformationsprozesse des modernen Kapitalismus. Aufsätze 1971-1987, ed. Daniel Bieber and Wilhelm Schumm. Frankfurt am Main: Suhrkamp.

Brandt, Gerhard. 1984. Marx und die neuere deutsche Industriesoziologie. Leviathan 12: 195-215.

Brandt, Gerhard. 1981. Ansichten kritischer Sozialforschung 1930-1980. In Institut für Sozialforschung: Gesellschaftliche Arbeit und Rationalisierung. Neuere Studien aus dem Institut für Sozialforschung in Frankfurt am Main, 9-56. Leviathan Sonderheft 4/1981. Opladen: Westdeutscher Verlag.

Braverman, Harry. 1998/1974. Labor and Monopoly Capital. The Degradation of Work in the Twentieth Century. New York: Monthly Review Press. 25th Anniversary Edition.

Dolata, Ulrich and Jan-Felix Schrape. 2013. Medien in Transformation. Radikaler Wandel als schrittweise Rekonfiguration. In: Internet, Mobile Devices und die Transformation der Medien. Radikaler Wandel als schrittweise Rekonfiguration, ed. Ulrich Dolata and Jan-Felix Schrape, 9-33. Berlin: sigma.

Eichler, Lutz, Hermann Kocyba and Wolfgang Menz. 2010. Gesellschaftstheoretischer Anspruch und die Beharrlichkeit des Besonderen. Theorie und Empirie in den industriesoziologischen Arbeiten des Instituts für Sozialforschung. In Industriesoziologische Fallstudien. Entwicklungspotenziale einer Forschungsstrategie, ed. Hans J. Pongratz and Rainer Trinczek, 163-201. Berlin: sigma.

Elbe, Ingo. 2008. Marx im Westen. Die neue Marx-Lektüre in der Bundesrepublik seit 1965. Berlin: Akademie Verlag.

Fuchs, Christian. 2011. Foundations of Critical Media and Information Studies. London/New York: Routledge.

Fuchs, Christian. 2009a. Grundlagen der Kritik der Politischen Ökonomie der Medien. In: Bruchstücke. Kritische Ansätze zu Politik und Ökonomie im globalisierten Kapitalismus, eds. Peter Fleissner and Natascha Wanek, 97-111. Berlin: Trafo.

Fuchs, Christian. 2009b. Some Theoretical Foundations of Critical Media Studies: Reflections on Karl Marx and the Media. International Journal of Communication 3: 369-402.

Fuchs, Christian. 2005. Intensivierung/Extensivierung der Arbeit. In Historisch-Kritisches Wörterbuch des Marxismus (HKWM) 6/II, ed. Wolfgang Fritz Haug, 1332-1337. Hamburg: Argument.

Harvey, David. 2018. A Companion to Marx's Capital: The Complete Edition. London: Verso.

Haug, Wolfgang Fritz. 2013. Das "Kapital" lesen - aber wie? Materialien zur Philosophie und Epistemologie der marxschen Kapitalismuskritik. Hamburg: Argument.

Haug, Wolfgang Fritz. 2012. Hightech-Kapitalismus in der Großen Krise. Hamburg: Argument. 
Haug, Wolfgang Fritz. 2008. Kapitalistische Produktionsweise. In Historisch-Kritisches Wörterbuch des Marxismus (HKWM) 7/l, ed. Wolfgang Fritz Haug, 292-316. Hamburg: Argument.

Haug, Wolfgang Fritz. 2005. Kapitalismus + Computer = ? Dimensionen der hochtechnologischen Produktionsweise. In Kritische Wissenschaften im Neoliberalismus, ed. Christina Kaindl, 107-123. Marburg: BdWi.

Haug, Wolfgang Fritz. 2003. High-Tech-Kapitalismus. Analysen zu Produktionsweise - Arbeit - Sexualität - Krieg \& Hegemonie. Hamburg: Argument.

Heinrich, Michael. 2011a. Die Wissenschaft vom Wert. Die Marxsche Kritik der politischen Ökonomie zwischen wissenschaftlicher Revolution und klassischer Tradition. Münster: Westfälisches Dampfboot. Fifth edition.

Heinrich, Michael. 2011b. Entstehungs- und Auflösungsgeschichte des Marxschen "Kapital ". In: Bonefeld, Werner/Heinrich, Michael (Hrsg.): Kapital \& Kritik. Nach der "neuen" MarxLektüre, ed. Werner Bonefeld and Michael Heinrich, 155-193. Hamburg: VSA.

Herkommer, Sebastian and Heinz Bierbaum. 1979. Industriesoziologie. Bestandsaufnahme, Kritik, Weiterentwicklung. Stuttgart: Ferdinand Enke.

Hoff, Jan. 2009. Marx global. Zur Entwicklung des internationalen Marx-Diskurses seit 1965. Berlin: Akademie Verlag.

Institut für Sozialforschung. 1981. Gesellschaftliche Arbeit und Rationalisierung. Neuere Studien aus dem Institut für Sozialforschung in Frankfurt am Main. Leviathan Sonderheft 4/1981. Opladen: Westdeutscher Verlag.

Jansen, Ulrich. 1983. Strukturveränderungen des journalistischen Arbeitsprozesses und deren Auswirkungen auf das beruflich vermittelte Bewußtsein. Frankfurt am Main: Haag+Herchen.

Jarren, Otfried, Matthias Künzler and Manuel Puppis, eds. 2012. Medienwandel oder Medienkrise? Folgen für Medienstrukturen und ihre Erforschung. Baden-Baden: Nomos.

Kisker, Klaus Peter. 1997. Strukturelle Überakkumulation und Krise der Erwerbsarbeit. ZZeitschrift für Marxistische Erneuerung 31: 61-68.

Knoche, Manfred. 2016. The Media Industry's Structural Transformation in Capitalism and the Role of the State: Media Economics in the Age of Digital Communications. tripleC: Communication, Capitalism \& Critique 14 (1): 18-47.

Knoche, Manfred. 2014. Befreiung von kapitalistischen Geschäftsmodellen: Entkapitalisierung von Journalismus und Kommunikationswissenschaft aus Sicht einer Kritik der politischen Ökonomie der Medien. In Journalismus ist kein Geschäftsmodell: Aktuelle Studien zur Ökonomie und Nicht-Ökonomie des Journalismus, ed. Frank Lobigs and Gerret Nordheim, 241-266. Baden-Baden: Nomos.

Knoche, Manfred. 2005. Entwicklung von Medientechniken als „Neue Medien“ aus der Sicht einer Kritik der Politischen Ökonomie der Medien. In Alte Medien - neue Medien. Theorieperspektiven, Medienprofile, Einsatzfelder, ed. Klaus Arnold and Christoph Neuberger, 40-62. Wiesbaden: VS.

Knoche, Manfred. 2002. Kommunikationswissenschaftliche Medienökonomie als Kritik der Politischen Ökonomie der Medien. In Medienökonomie in der Kommunikationswissenschaft. Bedeutung, Grundfragen und Entwicklungsperspektiven, ed. Gabriele Siegert, 101-109. Münster: LIT.

Knoche, Manfred. 2001. Kapitalisierung der Medienindustrie aus politökonomischer Perspektive. Medien \& Kommunikationswissenschaft 49 (2): 177-194.

Marx, Karl. 1894. Capital. A Critique of Political Economy. Volume Three. London: Penguin. Marx, Karl. 1885. Capital. A Critique of Political Economy. Volume Two. London: Penguin. Marx, Karl. 1867. Capital. A Critique of Political Economy. Volume One. London: Penguin. Marx, Karl. 1863-1865. Results of the Immediate Process of Production. In Capital Volume I, 941-1084. London: Penguin.

Marx, Karl. 1859. A Contribution to the Critique of Political Economy: Preface. In Marx \& Engels Collected Works (MECW) Volume 29, 261-265. London: Lawrence \& Wishart. 
Marx, Karl. 1847. The Poverty of Philosophy. Answer to the Philosophy of Poverty by M. Proudhon. In Marx \& Engels Collected Works (MECW) Volume 6, 105-212. London: Lawrence \& Wishart.

Mendner, Jürgen H. 1975. Technologische Entwicklung und Arbeitsprozess. Zur reellen Subsumtion der Arbeit unter das Kapital. Frankfurt am Main: Fischer.

Ohm, Christof and Frigga Haug. 2004. Hochtechnologische Produktionsweise. In Historischkritisches Wörterbuch des Marxismus (HKWM) 6/l, ed. Wolfgang Fritz Haug, 435-450. Hamburg: Argument.

Resch, Christine and Heinz Steinert. 2011. Kapitalismus: Porträt einer Produktionsweise. Münster: Westfälisches Dampfboot. Second edition.

Sauer, Dieter. 2006. Von der systemischen Rationalisierung zur permanenten Reorganisation. Lange und kurze Wellen der Unternehmensorganisation. In Informatisierung der Arbeit - Gesellschaft im Umbruch, ed. Andrea Baukrowitz, Thomas Berker, Andreas Boes, Sabine Pfeiffer, Rudi Schmiede and Mascha Will, 84-97. Berlin: Sigma.

Schmiede, Rudi. 2006. Wissen und Arbeit im "Informational Capitalism". In Informatisierung der Arbeit - Gesellschaft im Umbruch, ed. Andrea Baukrowitz, Thomas Berker, Andreas Boes, Sabine Pfeiffer, Rudi Schmiede and Mascha Will, 457-490. Berlin: Sigma.

Schmiede, Rudi. 1996. Informatisierung, Formalisierung und kapitalistische Produktionsweise. Entstehung der Informationstechnik und Wandel der gesellschaftlichen Arbeit. In Virtuelle Arbeitswelten. Arbeit, Produktion und Subjekt in der "Informationsgesellschaft", ed. Rudi Schmiede, 15-47. Berlin: Sigma.

Schmiede, Rudi. 1989. Reelle Subsumtion als gesellschaftstheoretische Kategorie. In Zur Entwicklungsdynamik des modernen Kapitalismus. Beiträge zur Gesellschaftstheorie, Industriesoziologie und Gewerkschaftsforschung. Symposium für Gerhard Brandt, ed. Wilhelm Schumm, 21-38. Frankfurt am Main: Campus.

Schütt, Bernd. 1981. Vom Tagesschriftsteller zum technischen Redakteur? Versuch einer logisch-historischen und empirischen Analyse journalistischer Tätigkeit. Frankfurt am Main: Haag+Herchen.

Smudits, Alfred. 2002. Mediamorphosen des Kulturschaffens. Kunst und Kommunikationstechnologien im Wandel. Wien: Braumüller.

Sohn-Rethel, Alfred. 1978. Intellectual and Manual Labour: A Critique of Epistemology. London: Macmillan.

Sohn-Rethel, Alfred. 1972. Die ökonomische Doppelnatur des Spätkapitalismus. Darmstadt/Neuwied: Luchterhand.

Teschner, Eckart and Klaus Hermann. 1981: Zur Taylorisierung technisch-geistiger Arbeit. Empirische Befunde und theoretische Überlegungen. In Institut für Sozialforschung: Gesellschaftliche Arbeit und Rationalisierung, 118-135. Opladen: Westdeutscher Verlag.

Weischenberg, Siegfried. 1982. Journalismus in der Computergesellschaft. Informatisierung, Medientechnik und die Rolle der Berufskommunikatoren. New York: Saur.

\section{About the Author}

Manfred Knoche

Manfred Knoche is professor emeritus of media economics at the University of Salzburg in Austria. He studied journalism, sociology, political science and economics at the University of Mainz and the Free University of Berlin. He obtained his PhD (1978) and defended his habilitation (1981) at the Free University of Berlin. He was research assistant in the years 19741979 and assistant professor for communications politics in Berlin in the years 1979-1983. From 1983-1994, he was professor of media and communication studies at the Vrije Universiteit Brussel in Belgium, where he was also the director of the Centre for Mass Communications Research. From 1994-2009 he held the chair professorship in media economics at the University of Salzburg in Austria, where he was Director of the Media Economics Group at the Department of Media and Communication Studies. He chaired the German Association for Media 
and Communication Studies' (DGPuK) media economics-section. He is author of many publications on the critique of the political economy of the media. His work has especially focused on the critique of the political economy of media concentration and the media industry's structural transformations.

http://www.medienoekonomie.at, https://kowi.uni-salzburg.at/ma/knoche-manfred/ Twitter: @Medoek 